\title{
ENTHALPY OF SOLVATION CORRELATIONS FOR GASEOUS SOLUTES \\ DISSOLVED IN CHLOROFORM AND 1,2-DICHLOROETHANE BASED ON THE ABRAHAM MODEL
}

\author{
Christina Mintz $^{\mathrm{a}}$, Katherine Burton ${ }^{\mathrm{a}}$, William E. Acree, Jr. ${ }^{\mathrm{a}^{*}}$ and Michael H. Abraham ${ }^{\mathrm{b}}$ \\ a Department of Chemistry, P. O. Box 305070, University of North Texas, \\ Denton, TX 76203-5070 (U.S.A.) \\ ${ }^{\mathrm{b}}$ Department of Chemistry, University College London, 20 Gordon Street, \\ London, WC1H 0AJ (U.K.)
}

\begin{abstract}
Enthalpy of solvation data have been compiled from the published literature for more than 80 solutes dissolved in chloroform and 1,2-dichloromethane. Mathematical correlations based on the Abraham general solvation parameter model are developed for describing the experimental solvation enthalpies to within standard deviations of 2.10 $\mathrm{kJ} / \mathrm{mole}$ (chloroform) and $1.72 \mathrm{~kJ} / \mathrm{mole}$ (1,2-dichloroethane). Division of the measured values into a training set and a test set shows that there is no bias in predictions, and that the estimative capability of the correlations is better than $2.5 \mathrm{~kJ} / \mathrm{mole}$.
\end{abstract}

Key Words: Enthalpy of solvation, enthalpy of transfer, mathematical correlation, partition coefficient, solvation parameter model

Short Running Title: Enthalpies of Solvation of Solutes in Chloroform and Dichloroethane 
*To whom correspondence should be addressed. (E-mail: acree@unt.edu) 


\section{Introduction}

The thermodynamic properties of molecules in various chemical and biological processes are greatly influenced by molecular interactions between the molecule and its solubilizing media. Such interactions may be either non-specific or specific in nature. Nonspecific interactions are described by a random distribution of molecules throughout the entire solution. Specific interactions, on the other hand, are generally much stronger and often result in a specific geometric orientation of one molecule with respect to an adjacent molecule. Even in systems known to contain specific interactions, the need to properly account for nonspecific interactions has been long recognized.

In recent studies we have developed mathematical correlation equations for predicting the enthalpies of solvation of gaseous solutes in water, $\Delta \mathrm{H}_{\mathrm{Solv}, \mathrm{w}}$, [1]

$$
\begin{aligned}
& \Delta \mathrm{H}_{\text {Solv }, \mathrm{W}}(\mathrm{kJ} / \mathrm{mole})=-13.310(0.457)+9.910(0.814) \mathbf{E}+2.836(0.807) \mathbf{S} \\
& -32.010(1.102) \mathbf{A}-41.816(0.781) \mathbf{B}-6.354(0.200) \mathbf{L} \\
& \left(\text { with } \mathrm{N}=368, \mathrm{SD}=3.68, \mathrm{R}^{2}=0.964, \mathrm{R}_{\text {adj }}^{2}=0.964, \mathrm{~F}=1950.5\right)
\end{aligned}
$$

and in several organic solvents, such as carbon tetrachloride, $\Delta \mathrm{H}_{\mathrm{Solv}, \mathrm{CT}}$, [2]

$\Delta \mathrm{H}_{\text {Solv }, \mathrm{CT}}(\mathrm{kJ} / \mathrm{mole})=-6.441(0.374)+3.517(0.703) \mathbf{E}-4.824(0.749) \mathbf{S}-7.045(0.740) \mathbf{B}$ $-8.886(0.129) \mathbf{L}$

$$
\text { (with } \mathrm{N}=177, \mathrm{SD}=2.070, \mathrm{R}^{2}=0.984, \mathrm{R}_{\text {adj }}^{2}=0.984, \mathrm{~F}=2681.8 \text { ) }
$$

and dimethyl sulfoxide, $\Delta \mathrm{H}_{\text {Solv,DMSO, }}[3]$

$$
\begin{aligned}
& \Delta \mathrm{H}_{\text {Solv,DMSO }}(\mathrm{kJ} / \mathrm{mole})=-2.546(0.703)-0.329(0.0 .952) \mathbf{E}-18.448(1.139) \mathbf{S}- \\
& 47.419(1.653) \mathbf{A}-5.861(1.004) \mathbf{B}-6.380(0.197) \mathbf{L} \\
& \left(\text { with } \mathrm{N}=150, \mathrm{SD}=2.80, \mathrm{R}^{2}=0.967, \mathrm{R}_{\text {adj }}^{2}=0.966, \mathrm{~F}=850.6\right)
\end{aligned}
$$


based on the Abraham solvation parameter model. Here and elsewhere, $\mathrm{N}$ corresponds to the number of solutes, $\mathrm{R}$ denotes the correlation coefficient, SD is the standard deviation and F corresponds to the Fisher F-statistic.

The independent variables in Eqns. 1-3 are as follows: $\mathbf{E}$ and $\mathbf{S}$ refer to the excess molar refraction and dipolarity/polarizability descriptors of the solute, respectively, $\mathbf{A}$ and $\mathbf{B}$ are the solute overall or summation hydrogen bond acidity and basicity, and $\mathbf{L}$ is the logarithm of the solute's gas phase dimensionless Ostwald partition coefficient into hexadecane at $298.15 \mathrm{~K}$. The first four descriptors can be regarded as measures of the tendency of the given solute to undergo various solute-solvent interactions. The latter descriptor, $\mathbf{L}$, is a measure of solute size, and will thus be a measure of the solvent cavity term that will accommodate the dissolved solute. General dispersion interactions are also related to solute size, hence, $\mathbf{L}$ will also describe the general solute-solvent interactions. The regression coefficients and constants $(c, e, s, a, b$, and $l)$ are obtained by regression analysis of experimental data for a given process, which in the case of Eqns. 1-3 was the enthalpic change resulting from the transfer of the gaseous solute into the respective liquid solvent.

Enthalpies of solvation are important in that the numerical values provide valuable information regarding solute-solvent interactions. From a thermodynamic standpoint, $\Delta \mathrm{H}_{\text {Solv }}$ data can be used to estimate the gas-to-condensed phase partition coefficient, $\mathrm{K}$,

$$
\ln K(a t T)-\ln K(\text { at } 298.15 K)=\frac{-\Delta H_{\text {Solv }}}{R}(1 / T-1 / 298.15)
$$

and the water-to-organic solvent partition coefficient, $\mathrm{P}$, 


$$
\ln P(a t T)-\ln P(\text { at } 298.15 K)=\frac{-\Delta H_{\text {trans }}}{R}(1 / T-1 / 298.15)
$$

at other temperatures from measured partition coefficient data at $298.15 \mathrm{~K}$ and the solute's enthalpy of solvation, $\Delta \mathrm{H}_{\text {Solv }}$, or enthalpy of transfer, $\Delta \mathrm{H}_{\text {trans }}$, between the two condensed phases. The enthalpy of transfer needed in Eqn. 5 is defined as

$$
\Delta \mathrm{H}_{\text {trans }}=\Delta \mathrm{H}_{\text {Solv, Org }}-\Delta \mathrm{H}_{\text {Solv }, \mathrm{W}}
$$

the difference in the enthalpy of solvation of the solute in the specified organic solvent minus its enthalpy of solvation in water. The above equations assume zero heat capacity changes. There is considerable published experimental partition coefficient data for solute transfer from water to water-immiscible (or partly miscible) organic solvents, such as 1-octanol, cyclohexane and heptane.

To date we have derived correlations for estimating the enthalpies of solvation of gaseous solutes in water, 1-octanol, heptane, hexadecane, cyclohexane, benzene, toluene, carbon tetrachloride, dimethyl sulfoxide and propylene carbonate [1-4]. Each correlation was based on experimental data for a minimum of 100 organic and inorganic solutes. Eventually, we hope to develop mathematical expressions for predicting enthalpies of solvation in most (if not all) of the organic solvents for which we have log $\mathrm{K}$ and $\log \mathrm{P}$ correlations. The present study concerns developing a $\Delta \mathrm{H}_{\text {Solv }}$ correlation for two chloroalkane solvent molecules, chloroform and 1,2-dichloroethane.

\section{Data Correlation and Computation Methods}

Our search of the published chemical and engineering literature found a large number of papers [5-65] that reported experimental partial molar enthalpies of solution of 
liquid and crystalline compounds in both chloroform and 1,2-dichloroethane. The experimental values were determined by either direct calorimetric methods or calculated based on the temperature dependence of the measured infinite dilution activity coefficients or solubilities. The retrieved enthalpy of solution values were converted to gas-to-organic solvent enthalpies of transfer by

$$
\begin{array}{ll}
\text { Liquid solutes: } & \Delta \mathrm{H}_{\text {Solv }}=\Delta \mathrm{H}_{\text {Soln }}-\Delta \mathrm{H}_{\text {Vap }, 298 \mathrm{~K}} \\
\text { Crystalline solutes: } & \Delta \mathrm{H}_{\text {Solv }}=\Delta \mathrm{H}_{\text {Soln }}-\Delta \mathrm{H}_{\text {Sub,298 }}
\end{array}
$$

subtracting the solute's standard molar enthalpy of vaporization [66], $\Delta \mathrm{H}_{\text {Vap,298K, }}$ or standard molar enthalpy of sublimation [67], $\Delta \mathrm{H}_{\text {Sub,298K }}$, at $298.15 \mathrm{~K}$. For purposes of the this study we have considered enthalpies of solvation, $\Delta \mathrm{H}_{\text {Solv }}$, and what will be called "inner energies", $\Delta \mathrm{U}_{\text {Solv, }}$, to be equivalent. Goss [68] discusses the difference between the $\Delta \mathrm{H}_{\text {Solv, }}$, and $\Delta \mathrm{U}_{\text {Solv, }}$ in terms of the concentration units used in expressing the gas-phase concentrations of the Henry's law constant. At $298 \mathrm{~K}$ the difference between the quantities amounts to about $2.5 \mathrm{~kJ} / \mathrm{mole}$ [68], which is less than the experimental uncertainty associated with many of the observed values. Given the slight numerical difference between the two values under normal environmental conditions, we have combined both sets of numerical values into a single database, as has been done in the past by most research groups that have developed predictive methods for enthalpies of solvation. Most of our tabulated values are enthalpies of solvation; however, there may be a few "inner energies" listed in Tables 1 and 2 that that were mislabeled as enthalpies in the original data source.

Based on an initial assessment of the available experimental data, we eliminated from consideration all experimental data that pertained to temperatures outside of the 
temperature range of $283 \mathrm{~K}-318 \mathrm{~K}$. Enthalpies of solvation are temperature dependent, and we did not want to introduce large errors in the database by including experimental data far removed from $298 \mathrm{~K}$. For several solutes there were multiple, independently determined values. In such cases, we selected direct calorimetric data over indirect values based on the temperature dependence of measured solubilities or infinite dilution activity coefficients. Using the fore-mentioned criteria, we obtained 100 molar enthalpies of solvation in chloroform and 88 molar enthalpies of solvation in 1,2dichloroethane for regression analysis. The experimental $\Delta \mathrm{H}_{\text {Solv,CFM }}$ and $\Delta \mathrm{H}_{\text {Solv,DCE }}$ values are listed in Tables 1 and 2, respectively, along with the literature references. For the analysis of the data, we use the two linear free energy equations of Abraham et al. [69,70]. In Eqn. 10, the descriptor $\mathbf{V}$ is the McGowan volume.

$$
\begin{aligned}
& \mathrm{SP}=\mathrm{c}+\mathrm{e} \cdot \mathbf{E}+\mathrm{s} \cdot \mathbf{S}+\mathrm{a} \cdot \mathbf{A}+\mathrm{b} \cdot \mathbf{B}+\mathrm{l} \cdot \mathbf{L} \\
& \mathrm{SP}=\mathrm{c}+\mathrm{e} \cdot \mathbf{E}+\mathrm{s} \cdot \mathbf{S}+\mathrm{a} \cdot \mathbf{A}+\mathrm{b} \cdot \mathbf{B}+\mathrm{v} \cdot \mathbf{V}
\end{aligned}
$$

Most of our precious studies have dealt with partition processes related to the Gibbs energy of transfer, where the dependent solute property, SP, would be either the logarithm of the gas-to-liquid (Eqn. 9) or the logarithm of the water-to-organic solvent (Eqn. 10) partition coefficient. The basic model can be used to correlate enthalpies of solvation and enthalpies of solute transfer from one condensed phase to a second condensed phase. Equations 1-3 correspond to the temperature derivative of the respective gas-to-liquid partition coefficient correlation; i.e., $\Delta \mathrm{H}_{\text {Solv }}=\mathrm{R} \partial \ln \mathrm{K} / \partial(1 / \mathrm{T})$. From a thermodynamic standpoint, the temperature derivative of the logarithm of the water-to-organic solvent partition coefficient would be related to enthalpy of transfer from water to the organic solvent, i.e., $\Delta \mathrm{H}_{\text {trans }}=\mathrm{R} \partial \ln \mathrm{P} / \partial(1 / \mathrm{T})$. We have also reported 
$\Delta \mathrm{H}_{\text {Solv }}$ correlations based on Eqn. 10, which uses the McGowan volume, V-descriptor, which is more readily available than the $\mathbf{L}$-descriptor. The $\mathbf{V}$-descriptor is easily calculable from the individual atomic sizes and numbers of bonds in the molecule [71]. Molecular descriptors for all of the compounds considered in the present study are tabulated in Tables 1 and 2. The numerical values of the solute descriptors came from our solute descriptor database, which now contains values for more than 4000 different organic and organometallic compounds. The descriptors were obtained exactly as described before, using various types of experimental data, including water to organic solvent partitions, solubility and chromatographic data [70].

\section{Results and Discussion}

We have assembled in Table 1 values of $\Delta \mathrm{H}_{\text {Solv, } \mathrm{CFM}}$ for 100 gaseous solutes dissolved in chloroform covering a reasonably wide range of compound type and descriptor values. Analysis of the experimental data yielded the following correlation equations

$$
\begin{aligned}
& \Delta \mathrm{H}_{\text {Solv }, \mathrm{CFM}}(\mathrm{kJ} / \mathrm{mole})=-6.516(0.701)+8.628(0.936) \mathbf{E}-13.956(1.160) \mathbf{S}- \\
& 2.712(1.666) \mathbf{A}-17.334(0.958) \mathbf{B}-8.739(0.158) \mathbf{L} \\
& \left(\text { with } \mathrm{N}=100, \mathrm{SD}=2.10, \mathrm{R}^{2}=0.982, \mathrm{R}_{\text {adj }}^{2}=0.981, \mathrm{~F}=1049.5\right) \\
& \Delta \mathrm{H}_{\text {Solv }, \mathrm{CFM}}(\mathrm{kJ} / \mathrm{mole})=-0.425(0.829)-0.844(0.916) \mathbf{E}-20.735(1.251) \mathbf{S}- \\
& \quad 5.817(1.753) \mathbf{A}-16.434(1.003) \mathbf{B}-31.039(0.587) \mathbf{V} \\
& \left(\text { with } \mathrm{N}=100, \mathrm{SD}=2.19, \mathrm{R}^{2}=0.981, \mathrm{R}_{\text {adj }}^{2}=0.980, \mathrm{~F}=964.5\right)
\end{aligned}
$$


All regression analyses were performed using SPSS statistical software. Both Eqn. 11 and 12 are statistically very good with standard deviations of 2.10 and $2.19 \mathrm{~kJ} / \mathrm{mole}$ for a data set that covers a range of $106.89 \mathrm{~kJ} / \mathrm{mole}$. See Figure 1 for a plot of the calculated values of $\Delta \mathrm{H}_{\text {Solv,CFM }}$ based on Eqn. 11 against the observed values. Equation 11 is slightly the better equation statistically, and from a thermodynamic standpoint Eqn. 11 is the enthalpic temperature derivative of the Abraham model's gas-to-condensed phase transfer equation. Equation 12 might be more useful in some predictive applications in instances where the $\mathbf{L}$-descriptor is not known. Equation 12 uses the McGowan volume, V-descriptor, which is easily calculable from the individual atomic sizes and numbers of bonds in the molecule [71]. To our knowledge, equations 11 and 12 are the first expressions that allow one to predict the enthalpy of solvation of gaseous solutes in chloroform.

In order to assess the predictive ability of Eqn. 11 we divided the 100 data points into a training set and a test set by allowing the SPSS software to randomly select half of the experimental data points. The selected data points became the training set and the compounds that were left served as the test set. Analysis of the experimental data in the training set gave

$\Delta \mathrm{H}_{\text {Solv }, \mathrm{CFM}}(\mathrm{kJ} / \mathrm{mole})=-6.291(0.775)+7.456(1.008) \mathbf{E}-13.902(1.237) \mathbf{S}-4.694(2.179)$

$$
\mathbf{A}-15.674(1.082) \mathbf{B}-8.734(0.168) \mathbf{L}
$$

(with $\mathrm{N}=50, \mathrm{SD}=1.66, \mathrm{R}^{2}=0.988, \mathrm{R}_{\text {adj }}^{2}=0.987, \mathrm{~F}=746.1$ )

The training set equation, Eqn. 13, was then used to predict $\Delta \mathrm{H}_{\text {Solv, CFM }}$ for the 50 compounds in the test set. Comparison of the predicted and observed values gave SD = 2.24, Average Absolute Error $(\mathrm{AAE})=1.60$ and an Average Error $(\mathrm{AE})=-0.3705$. 
There is therefore very little bias in the predictions using Eqn. 13 with AE equal to $0.3705 \mathrm{~kJ} / \mathrm{mole}$. To our knowledge there has been no previous attempt to correlate $\Delta \mathrm{H}_{\text {Solv,CFM }}$ data.

In Table 2 are collected values of the enthalpies of solvation of 88 gaseous solutes in 1,2-dichloroethane. Regression analyses of the experimental $\Delta \mathrm{H}_{\mathrm{Solv} \text {, DCE }}$ data in accordance with the Abraham model yielded

$$
\begin{gathered}
\Delta \mathrm{H}_{\mathrm{Solv}, \mathrm{DCE}}=-2.345(0.672)+5.555(0.861) \mathbf{E}-18.328(1.122) \mathbf{S}-9.599(1.794) \mathbf{A}- \\
7.101(1.013) \mathbf{B}-8.045(0.144) \mathbf{L}
\end{gathered}
$$

(with $\mathrm{N}=88, \mathrm{SD}=1.72, \mathrm{R}^{2}=0.982, \mathrm{R}^{2}{ }_{\text {adj }}=0.980, \mathrm{~F}=875.3$.)

$$
\begin{aligned}
& \Delta \mathrm{H}_{\mathrm{Solv}, \mathrm{DCE}}=3.623(1.002)-3.208(1.050) \mathbf{E}-24.665(1.520) \mathbf{S}-11.165(2.348) \mathbf{A}- \\
& 6.589(1.322) \mathbf{B}-28.520(0.671) \mathbf{V}
\end{aligned}
$$

(with $\mathrm{N}=88, \mathrm{SD}=2.24, \mathrm{R}^{2}=0.969, \mathrm{R}^{2}{ }_{\mathrm{adj}}=0.967, \mathrm{~F}=509.1$ )

Both Eqn. (14) and (15) are statistically very good with standard deviations of 1.72 and $2.24 \mathrm{~kJ} / \mathrm{mole}$ for a data set that covers a range of $71.7 \mathrm{~kJ} / \mathrm{mole}$. Figure 2 compares the calculated values of $\Delta \mathrm{H}_{\text {Solv,DCE }}$ based on Eqn. (14) against the observed values. To our knowledge there has been no previous attempt to correlate $\Delta \mathrm{H}_{\text {Solv,DCE }}$ data.

In order to assess the predictive ability of Eqn. 14 we divided the 88 data points into a training set and a test set by allowing the SPSS software to randomly select half of the experimental data points. The selected data points became the training set and the remaining compounds that were left served as the test set. Analysis of the experimental data in the training set gave $\Delta \mathrm{H}_{\text {Solv,DCE }}(\mathrm{kJ} / \mathrm{mole})=-2.972(0.943)+4.717(1.443) \mathbf{E}-17.267(1.804) \mathbf{S}-$ 


$$
\text { 5.233(2.530) A - 8.317(1.984) B - 7.886(0.181) L }
$$

(with $\mathrm{N}=44, \mathrm{SD}=1.48, \mathrm{R}^{2}=0.983, \mathrm{R}^{2}$ adj $=0.980, \mathrm{~F}=432.7$ )

The training set equation, Eqn. 13, was then used to predict $\Delta \mathrm{H}_{\text {Solv,DCE }}$ for the 44 compounds in the test set. Comparison of the predicted and observed values gave $\mathrm{SD}=$ 2.07, Average Absolute Error $(\mathrm{AAE})=1.54$ and an Average Error $(\mathrm{AE})=-0.0764$. There is therefore very little bias in the predictions using Eqn. 16 with AE equal to $0.0764 \mathrm{~kJ} / \mathrm{mole}$. An uncertainty/error of $\pm 2 \mathrm{~kJ} / \mathrm{mole}$ in the enthalpy of solvation results in an error of slightly less than $0.04 \log$ units in extrapolating a log $\mathrm{K}$ value measured at 298.15 K to $313.15 \mathrm{~K}$. This level of error will be sufficient for most practical chemical and engineering applications. To our knowledge there has been no previous attempt to correlate $\Delta \mathrm{H}_{\text {Solv,DCE }}$ data.

As noted previously, correlations for predicting enthalpies of solvation in the various organic solvents can be combined with Eqn. 1 to give enthalpies of solute transfer from water to the given organic solvent. Enthalpies of solute transfer are particularly useful in that knowledge of $\Delta \mathrm{H}_{\text {trans }}$ enables one to predict how water-to-organic solvent partition coefficients vary with temperature. There is considerable published partition coefficient data for solutes distributed between water and chloroform [72, 73], and between water and 1,2-dichloroethane $[72,74,75]$. Solutes studied include nonionic molecules as well as ionizable drugs. Most of the published data pertain to $298 \mathrm{~K}$, and the correlations presented in the present study will allow one to estimate $\log \mathrm{P}$ values at temperatures not too far removed from $298 \mathrm{~K}$. 


\section{References}

[ 1] C. Mintz, M. Clark, W. E. Acree, Jr., M. H. Abraham, J. Chem. Inf. Model. 47 (2007) 115-121.

[ 2] C. Mintz, M. Clark, K. Burton, W. E. Acree, Jr., M. H. Abraham, J. Solution Chem., accepted for publication.

[ 3] C. Mintz, K. Burton, W. E. Acree, Jr., M. H. Abraham, Thermochim. Acta, available online as an accepted article - doi: 10.1016/j.tca.2007.04.005.

[ 4] C. Mintz, M. Clark, K. Burton, W. E. Acree, Jr., M. H. Abraham, QSAR \& Comb. Sci., available online as an accepted article - doi:

10.1002/qsar.2006.30156.

[ 5] J. Ortega, J. Placido, ELDATA: Int. Elec. J. Physico-Chem. Data 1 (1995) 5967.

[ 6] T. E. Burchfield, Ph.D. Dissertation, University of Missouri-Rolla (1977).

[ 7] J. J. Christensen, R. L. Rowley, R. M. Izatt, Handbook of Heats of Mixing: Supplementary Volume, John Wiley and Sons, Inc., New York, NY, 524 (1988).

[ 8] V. B. Novikov, D. I. Abaidullina, N. Z. Gainutdinova, M. A. Varfalomeev, B. N. Solomonov, Russ. J. Phys. Chem. 80 (2006) 1790-1794.

[9] H. Ogawa, S. Murakami, T. Takigawa, M. Ohba, Fluid Phase Equilibr. 136 (1997) 279-287.

[10] J. L. Chevalier, P. Goursot, J. Balade, Compt. Rend. des Seances l'Acad. des Sci., Ser. C: Sci. Chim. 266 (1968) 326-1328.

[11] Z. E. Ilic, Z. B. Maksimovic, Thermochim. Acta 53 (1982) 251-256.

[12] S. C. Sharma, J. Singh, J. Solution Chem. 24 (1995) 145-151. 
[13] F. Becker, F. Hallauer, Int. DATA Ser., Sel. Data Mix., Ser. A (1988) 45.

[14] A. Inglese, A. Thermochim. Acta 199 (1992) 173-187.

[15] Y. Takeda, T. Watanabe, H. Yamada, S. Katsuta, J. Mol. Liq. 108 (2003) 151173.

[16] T. Ohta, Int. DATA Ser., Sel. Data Mix., Ser. A (1998) 298.

[17] T. Ohta, Int. DATA Ser., Sel. Data Mix., Ser. A (1998) 286.

[18] M. Jozwiak, Thermochim. Acta 417 (2004) 31-41.

[19] V. P. Barannikov, S. S. Guseynov, A. I. Vyugin, J. Chem. Thermodyn. 36 (2004) 277-280.

[20] J. Ortega, Int. DATA Ser., Sel. Data Mix., Ser. A (1993) 40.

[21] J. Ortega, Int. DATA Ser., Sel. Data Mix., Ser. A (1993) 41.

[22] J. Ortega, Int. DATA Series, Sel. Data Mix., Ser. A (1993) 43.

[23] J. Ortega, Int. DATA Ser., Sel. Data Mixtures, Ser. A (1993) 44.

[24] J. Ortega, International DATA Series, Selected Data Mix., Series A (1993) 45.

[25] J. Ortega, Int. DATA Ser., Sel. Data Mix., Ser. A (1993) 46.

[26] J. Ortega, Int. DATA Ser., Sel. Data Mix., Ser. A (1993) 47.

[27] J. J. Moura Ramos, M. L. Stien, J. Reisse, Chem. Phys. Letters 42 (1976) 373375.

[28] J. N. Spencer, E. S. Holmboe, D. W. Firth, M. R. Kirshenbaum, J. Solution Chem. 10 (1981) 745-756.

[29] J. N. Spencer, J. E. Gleim, C. H. Blevins, R. C. Garrett, F. J. Mayer, J. Phys. Chem. 83 (1979) 1249-1255. 
[30] J. Munoz Embid, A. H. Roux, J. P. E. Grolier, Int. DATA Ser., Sel. Data Mix., Ser. A (1990) 66.

[31] J. Munoz Embid, A. H. Roux, J. P. E. Grolier, Int. DATA Ser., Sel. Data Mix., Ser. A (1990) 67.

[32] J. Munoz Embid, A. H. Roux, J. P. E. Grolier, Int. DATA Ser., Sel. Data Mix., Ser. A (1990) 77.

[33] B. N. Solomonov, V. B. Novikov, M. A. Varfolomeev, A. E. Klimovitskii, J. Phys. Org. Chem. 18 (2005) 1132-1137.

[34] J. Placido, J. Ortega, H. V. Kehiaian, ELDATA: Int. Elec. J. Physico-Chem. Data 1 (1995) 239-248.

[35] J. Ortega, J. Placido, ELDATA: The Int. Elec. J. Physico-Chem. Data 2 (1996) $85-96$.

[36] D. F. Gray, N. F. Pasco, A. G. Williamson, J. Chem. Eng. Data 33 (1988) 333334.

[37] B. N. Solomonov, I. S. Antipin, V. V. Gorbachuk, A. I. Konovalov, A. I. Russ. J. Gen. Chem. 48 (1978) 2113-2116.

[38] D. Fenclova, P. Vrbka, V. Dohnal, K. Rehak, G. Garcia-Miaja, J. Chem. Thermodyn. 34 (2002) 361-376.

[39] E. R. Thomas, B. A. Newman, G. L. Nicolaides, C. A. Eckert, J. Chem. Eng. Data 27 (1982) 233-240.

[40] W. Riebesehl, E. Tomlinson, P. R. Niemel, J. Solution Chem. 14 (1985) 699-707.

[41] V. I. Smirnov, E. V. Kastorina, G. L. Perlovich, A. Ya. Fridman, Zhur. Fiz. Khim. 66 (1992) 1466-1470. 
[42] R. Fuchs, W. K. Stephenson, Can. J. Chem. 63 (1985) 349-352.

[43] W. K. Stephenson, R. Fuchs, Can. J. Chem. 63 (1985) 336-341.

[44] C. Airoldi, S. Roca, J. Solution Chem. 22 (1993) 707-713.

[45] B. N. Solomonov, F. T. Khafizov, V. V. Gorbachuk, Zh. Obshch. Khim. 60 (1990) 1446-1452.

[46] W. K. Stephenson, R. Fuchs, Can. J. Chem. 63 (1985) 342-348.

[47] J. Ortega, E. Marrero, F. J. Toledo, F. Espiau, J. Chem. Thermodyn. 37 (2005) 1332-1346.

[48] J. Ortega, J. Placido, Int. DATA Ser., Sel. Data Mix., Ser. A (1993) 6.

[49] J. Ortega, J. Placido, Int. DATA Ser., Sel. Data Mix., Ser. A (1993) 7.

[50] J. Ortega, J. Placido, Int. DATA Ser., Sel. Data Mix., Ser. A (1993) 8.

[51] J. Ortega, J. Placido, Int. DATA Ser., Sel. Data Mix., Ser. A (1993) 9.

[52] S. K. Chaudhari, S. S. Katti, Thermochim. Acta 158 (1990) 99-106.

[53] J. N. Spencer, J. E. Mihalick, I. M. Paul, W. J. Nicholson, T. J.; Nicholson, X. Ke, Q. He, F. J. Carter, S. E. Daniels, J. Solution Chem. 23 (1994) 721-734.

[54] J. Ortega, E. Marrero, J. Chem. Thermodyn. 39 (2007) 742-757.

[55] J. Ortega, E. Marrero, F. J. Toledo, J. Chem. Thermodyn. 38 (2006) 1139-1149.

[56] F. Comelli, R. Francesconi, J. Chem. Eng. Data 40 (1995) 509-511.

[56] F. Comelli, R. Francesconi, H. V. Kehiaian, J. Chem. Eng. Data 36 (1991) 485487.

[57] F. Comelli, R. Francesconi, J. Chem. Eng. Data 39 (1994) 560-564.

[58] J. Munoz Embid, C. Berro, S. Otin, Int. DATA Ser., Sel. Data Mix., Ser. A (1991) 272 . 
[59] G. Hahn, P. Svejda, Int. DATA Ser., Sel. Data Mix., Ser. A (1985) 146.

[60] D. Figeys, M. Koschmidder, R. L. Benoit, Can. J. Chem. 70 (1992) 1586-1589.

[61] R. L. Benoit, E. Milanova, Can. J. Chem. 57 (1979) 1319-23.

[62] J. Munoz Embid, C. Berro, S. Otin, Int. DATA Ser., Sel. Data Mix., Ser. A (1991) 273.

[63] J. Munoz Embid, A. H. Roux, J. P. E. Grolier, Int. DATA Ser., Sel. Data Mix., Ser. A (1990) 71.

[64] I. Putze, R. Garriga, P. Perez, M. Gracia, J. Chem. Thermodyn. 27 (1995) 11531159.

[65] F. T. Khafizov, V. A. Breus, O. E. Kiselev, B. N. Solomonov, A. I. Konovalov, Zhur. Obshch. Khim. 60 (1990) 721-730.

[66] J. S. Chickos, W. E. Acree, Jr. J. Phys. Chem. Ref. Data 32 (2003) 519-878.

[67] J. S. Chickos, W. E. Acree, Jr. J. Phys. Chem. Ref. Data 31 (2002) 537-698.

[68] K.-U. Goss, Chemosphere 64, 2006, 1369-1374

[69] M. H. Abraham, Chem. Soc. Rev. 22 (1993) 73-83.

[70] M. H. Abraham, A. Ibrahim, A. M. Zissimos, J. Chromatogr. A 1037 (2004) 2947.

[71] M. H. Abraham, J. C. McGowan, Chromatographia 23 (1987) 243-246.

[72] A. J. Leo, The Medicinal Chemistry Project, Pomona College, Claremont, CA 91711, USA (2006).

[73] M. H. Abraham, J. A. Platts, A. Hersey, A. J. Leo, R. W. Taft, J. Pharm. Sci. 88 (1999) 670-679. 
[74] F. Reymond, V. Chopineaux-Courtois, G. Steyaert, G. Bouchard, P.-A. Carrupt, B. Testa, H. H. Girault, J. Electroanal. Chem. 462 (1999) 235-250.

[75] G. Steyaert, G. Lisa, P. Gaillard, G. Boss, F. Reymond, H. H. Girault, P.-A. Carrupt, B. Testa, J. Chem. Soc., Faraday Trans. 93 (1997) 401-406. 
TABLE 1. Values of the gas to chloroform solvation enthalpy, $\Delta \mathrm{H}_{\text {Solv, CFM, in } \mathrm{kJ} / \mathrm{mole} \text { at }}$ $298 \mathrm{~K}$ for 100 solutes, together with the solute descriptors

\begin{tabular}{|c|c|c|c|c|c|c|c|c|}
\hline Solute & E & S & A & $B$ & $\mathbf{L}$ & V & Exp & Ref \\
\hline Pentane & 0.000 & 0.000 & 0.000 & 0.000 & 2.162 & 0.8131 & -24.21 & 5 \\
\hline Hexane & 0.000 & 0.000 & 0.000 & 0.000 & 2.668 & 0.9540 & -28.25 & 5 \\
\hline Heptane & 0.000 & 0.000 & 0.000 & 0.000 & 3.173 & 1.0949 & -32.95 & 5 \\
\hline Octane & 0.000 & 0.000 & 0.000 & 0.000 & 3.677 & 1.2358 & -37.57 & 5 \\
\hline Nonane & 0.000 & 0.000 & 0.000 & 0.000 & 4.182 & 1.3767 & -41.95 & 5 \\
\hline Decane & 0.000 & 0.000 & 0.000 & 0.000 & 4.686 & 1.5176 & -46.12 & 5 \\
\hline Undecane & 0.000 & 0.000 & 0.000 & 0.000 & 5.191 & 1.6585 & -51.27 & 5 \\
\hline Dodecane & 0.000 & 0.000 & 0.000 & 0.000 & 5.696 & 1.7994 & -55.83 & 5 \\
\hline \begin{tabular}{|l|} 
Tridecane \\
\end{tabular} & 0.000 & 0.000 & 0.000 & 0.000 & 6.200 & 1.9402 & -60.03 & 5 \\
\hline Tetradecane & 0.000 & 0.000 & 0.000 & 0.000 & 6.705 & 2.0810 & -65.37 & 5 \\
\hline Pentadecane & 0.000 & 0.000 & 0.000 & 0.000 & 7.209 & 2.2220 & -67.72 & 5 \\
\hline Hexadecane & 0.000 & 0.000 & 0.000 & 0.000 & 7.714 & 2.3630 & -73.95 & 5 \\
\hline Heptadecane & 0.000 & 0.000 & 0.000 & 0.000 & 8.218 & 2.5040 & -78.09 & 5 \\
\hline Cyclohexane & 0.305 & 0.100 & 0.000 & 0.000 & 2.964 & 0.8454 & -30.29 & 6 \\
\hline Cycloheptane & 0.350 & 0.100 & 0.000 & 0.000 & 3.704 & 0.9863 & -35.97 & 7 \\
\hline Cyclooctane & 0.413 & 0.100 & 0.000 & 0.000 & 4.329 & 1.1272 & -40.81 & 7 \\
\hline Benzene & 0.610 & 0.520 & 0.000 & 0.140 & 2.786 & 0.7176 & -35.85 & 8 \\
\hline Toluene & 0.601 & 0.520 & 0.000 & 0.140 & 3.325 & 0.8573 & -41.09 & 8 \\
\hline \begin{tabular}{|l|} 
1,4-Dimethylbenzene \\
\end{tabular} & 0.613 & 0.520 & 0.000 & 0.160 & 3.839 & 0.9982 & -46.20 & 8 \\
\hline 1,3,5-Trimethylbenzene & 0.649 & 0.520 & 0.000 & 0.190 & 4.344 & 1.1391 & -50.29 & 8 \\
\hline Naphthalene & 1.340 & 0.920 & 0.000 & 0.200 & 5.161 & 1.0854 & -57.18 & 9 \\
\hline Phenanthrene & 2.055 & 1.290 & 0.000 & 0.260 & 7.632 & 1.4540 & -77.17 & 9 \\
\hline Anthracene & 2.290 & 1.340 & 0.000 & 0.280 & 7.568 & 1.4540 & -78.45 & 9 \\
\hline Diethyl ether & 0.041 & 0.250 & 0.000 & 0.450 & 2.015 & 0.7309 & -36.40 & 8 \\
\hline Dipropyl ether & 0.008 & 0.250 & 0.000 & 0.450 & 2.954 & 1.0127 & -42.20 & 10 \\
\hline Diisopropyl ether & -0.060 & 0.160 & 0.000 & 0.580 & 2.530 & 1.0127 & -41.28 & 10 \\
\hline Dibutyl ether & 0.000 & 0.250 & 0.000 & 0.450 & 3.924 & 1.2945 & -51.00 & 8 \\
\hline Dipentyl ether & 0.000 & 0.250 & 0.000 & 0.450 & 4.875 & 1.5763 & -57.19 & 11 \\
\hline Ethoxypropane & 0.000 & 0.250 & 0.000 & 0.450 & 2.493 & 0.8718 & -38.73 & 10 \\
\hline Ethoxybutane & 0.013 & 0.250 & 0.000 & 0.450 & 2.989 & 1.0127 & -46.90 & 10 \\
\hline Methyl tert-butyl ether & 0.024 & 0.110 & 0.000 & 0.630 & 2.380 & 0.8718 & -38.53 & 12 \\
\hline Furan & 0.369 & 0.510 & 0.000 & 0.130 & 1.913 & 0.5363 & -29.14 & 13 \\
\hline Tetrahydrofuran & 0.289 & 0.520 & 0.000 & 0.480 & 2.636 & 0.6223 & -42.60 & 8 \\
\hline Tetrahydropyran & 0.275 & 0.470 & 0.000 & 0.550 & 3.057 & 0.7672 & -43.98 & 14 \\
\hline 1,3-Dioxane & 0.308 & 0.720 & 0.000 & 0.700 & 2.519 & 0.6810 & -48.20 & 14 \\
\hline 1,4-Dioxane & 0.329 & 0.750 & 0.000 & 0.640 & 2.892 & 0.6810 & -49.70 & 8 \\
\hline Digylme & 0.113 & 0.760 & 0.000 & 1.170 & 3.920 & 1.1301 & -72.40 & 8 \\
\hline 15-Crown-5 & 0.410 & 1.200 & 0.000 & 1.750 & 6.779 & 1.7025 & -105.58 & 15,18 \\
\hline 18-Crown-6 & 0.400 & 1.340 & 0.000 & 2.130 & 7.919 & 2.0430 & -131.10 & 19 \\
\hline Acetone & 0.179 & 0.700 & 0.040 & 0.490 & 1.696 & 0.5470 & -39.34 & 8 \\
\hline
\end{tabular}




\begin{tabular}{|c|c|c|c|c|c|c|c|c|}
\hline 2-Butanone & 0.166 & 0.700 & 0.000 & 0.510 & 2.287 & 0.6879 & -43.51 & 16 \\
\hline 3-Pentanone & 0.154 & 0.660 & 0.000 & 0.510 & 2.811 & 0.8288 & -47.76 & 11 \\
\hline 4-Heptanone & 0.110 & 0.660 & 0.000 & 0.510 & 3.705 & 1.1106 & -56.07 & 11 \\
\hline 5-Nonanone & 0.103 & 0.660 & 0.000 & 0.510 & 4.698 & 1.3924 & -63.26 & 11 \\
\hline Cyclohexanone & 0.403 & 0.860 & 0.000 & 0.560 & 3.792 & 0.8610 & -55.90 & 27 \\
\hline N,N-Dimethylformamide & 0.367 & 1.310 & 0.000 & 0.740 & 3.173 & 0.6468 & -60.00 & 8 \\
\hline Dimethyl sulfoxide & 0.522 & 1.720 & 0.000 & 0.970 & 3.459 & 0.6126 & -66.69 & 8 \\
\hline Ethyl formate & 0.146 & 0.660 & 0.000 & 0.380 & 1.845 & 0.6057 & -35.02 & 20 \\
\hline Propyl formate & 0.132 & 0.630 & 0.000 & 0.380 & 2.433 & 0.7466 & -43.97 & 21 \\
\hline Methyl acetate & 0.142 & 0.640 & 0.000 & 0.450 & 1.911 & 0.6057 & -39.68 & 17 \\
\hline Ethyl acetate & 0.106 & 0.620 & 0.000 & 0.450 & 2.314 & 0.7466 & -43.84 & 8 \\
\hline Propyl acetate & 0.092 & 0.600 & 0.000 & 0.450 & 2.819 & 0.8875 & -49.37 & 22 \\
\hline Ethyl propanoate & 0.087 & 0.580 & 0.000 & 0.450 & 2.807 & 0.8875 & -48.91 & 23 \\
\hline Propyl propanoate & 0.070 & 0.560 & 0.000 & 0.450 & 3.338 & 1.0284 & -53.24 & 24 \\
\hline Ethyl butanoate & 0.068 & 0.580 & 0.000 & 0.450 & 3.271 & 1.0284 & -52.85 & 25 \\
\hline Propyl butanoate & 0.05 & 0.560 & 0.000 & 0.450 & 3.783 & 1.1693 & -56.77 & 26 \\
\hline Triethylamine & 0.101 & 0.150 & 0.000 & 0.790 & 3.040 & 1.0538 & -46.40 & 8 \\
\hline Aniline & 0.955 & 0.960 & 0.260 & 0.410 & 3.934 & 0.8162 & -56.10 & 8 \\
\hline N,N-Dimethylaniline & 0.957 & 0.810 & 0.000 & 0.410 & 4.701 & 1.0980 & -58.23 & 8 \\
\hline Pyridine & 0.631 & 0.840 & 0.000 & 0.520 & 3.022 & 0.6753 & -48.40 & 8 \\
\hline Acetonitrile & 0.237 & 0.900 & 0.070 & 0.320 & 1.739 & 0.4042 & -36.93 & 8 \\
\hline Nitromethane & 0.313 & 0.950 & 0.060 & 0.310 & 1.892 & 0.4237 & -37.70 & 8 \\
\hline \begin{tabular}{|l|} 
Methanol \\
\end{tabular} & 0.278 & 0.440 & 0.430 & 0.470 & 0.970 & 0.3082 & -28.70 & 8 \\
\hline Ethanol & 0.246 & 0.420 & 0.370 & 0.480 & 1.485 & 0.4491 & -32.80 & 8 \\
\hline 1-Propanol & 0.236 & 0.420 & 0.370 & 0.480 & 2.031 & 0.5900 & -35.20 & 33 \\
\hline 2-Propanol & 0.212 & 0.360 & 0.330 & 0.560 & 1.764 & 0.5900 & -35.10 & 8 \\
\hline 1-Butanol & 0.224 & 0.420 & 0.370 & 0.480 & 2.601 & 0.7309 & -42.00 & 8 \\
\hline 1-Hexanol & 0.210 & 0.420 & 0.370 & 0.480 & 3.610 & 1.0170 & -50.40 & 8 \\
\hline 1-Octanol & 0.199 & 0.420 & 0.370 & 0.480 & 4.619 & 1.2950 & -60.00 & 8 \\
\hline Dichloromethane & 0.387 & 0.570 & 0.100 & 0.050 & 2.019 & 0.4943 & -30.32 & 7 \\
\hline Chloroform & 0.425 & 0.490 & 0.150 & 0.020 & 2.480 & 0.6167 & -31.31 & 66 \\
\hline 1-Chlorobutane & 0.210 & 0.400 & 0.000 & 0.100 & 2.722 & 0.7946 & -35.06 & 30 \\
\hline 1,2-Dichloroethane & 0.416 & 0.640 & 0.100 & 0.110 & 2.573 & 0.6352 & -35.65 & 31 \\
\hline 1,1,2,2-Tetrachloroethane & 0.595 & 0.760 & 0.160 & 0.120 & 3.803 & 0.8800 & -45.63 & 32 \\
\hline Phenol & 0.805 & 0.890 & 0.600 & 0.300 & 3.766 & 0.7751 & -51.00 & 28 \\
\hline 2-Methoxyphenol & 0.837 & 0.910 & 0.220 & 0.520 & 4.449 & 0.9160 & -61.98 & 28 \\
\hline Anisole & 0.710 & 0.750 & 0.000 & 0.290 & 3.890 & 0.9160 & -50.44 & 28 \\
\hline Pyrrole & 0.613 & 0.730 & 0.410 & 0.290 & 2.865 & 0.5770 & -41.12 & 29 \\
\hline N-Methylpyrrole & 0.559 & 0.790 & 0.000 & 0.310 & 2.923 & 0.7180 & -46.73 & 29 \\
\hline N-Methylaniline & 0.948 & 0.900 & 0.170 & 0.430 & 4.494 & 0.9571 & -56.76 & 29 \\
\hline N-Ethylaniline & 0.945 & 0.850 & 0.170 & 0.430 & 4.811 & 1.0980 & -60.81 & 29 \\
\hline Diethyl sulfide & 0.373 & 0.380 & 0.000 & 0.320 & 3.104 & 0.8357 & -43.50 & 36 \\
\hline Piperidine & 0.422 & 0.460 & 0.100 & 0.690 & 3.304 & 0.8043 & -49.51 & 38 \\
\hline Nitrobenzene & 0.871 & 1.110 & 0.000 & 0.280 & 4.557 & 0.8906 & -59.20 & 37 \\
\hline Bromoethane & 0.366 & 0.400 & 0.000 & 0.120 & 2.120 & 0.5654 & -27.90 & 39 \\
\hline 1,2-Diaminobenzene & 1.260 & 1.400 & 0.240 & 0.730 & 4.845 & 0.9148 & -61.40 & 41 \\
\hline
\end{tabular}




\begin{tabular}{|l|l|l|l|l|l|l|l|l|}
\hline 1-Chloropentane & 0.208 & 0.380 & 0.000 & 0.090 & 3.223 & 0.9355 & -40.17 & 34 \\
\hline 1-Chlorohexane & 0.201 & 0.400 & 0.000 & 0.100 & 3.777 & 1.0770 & -44.44 & 34 \\
\hline 1-Chloroheptane & 0.194 & 0.400 & 0.000 & 0.100 & 4.282 & 1.2178 & -48.99 & 34 \\
\hline 1-Chlorooctane & 0.191 & 0.400 & 0.000 & 0.100 & 4.772 & 1.3585 & -53.47 & 34 \\
\hline Methyl propanoate & 0.128 & 0.600 & 0.000 & 0.450 & 2.431 & 0.7466 & -45.05 & 35 \\
\hline Methyl butanoate & 0.106 & 0.600 & 0.000 & 0.450 & 2.893 & 0.8875 & -50.40 & 35 \\
\hline Methyl pentanoate & 0.108 & 0.600 & 0.000 & 0.450 & 3.392 & 1.0284 & -52.59 & 35 \\
\hline Methyl hexanoate & 0.08 & 0.600 & 0.000 & 0.450 & 3.874 & 1.1693 & -57.93 & 35 \\
\hline Methyl octanoate & 0.065 & 0.600 & 0.000 & 0.450 & 4.838 & 1.4511 & -67.35 & 35 \\
\hline Methyl nonanoate & 0.056 & 0.600 & 0.000 & 0.450 & 5.321 & 1.5920 & -70.94 & 35 \\
\hline Methyl decanoate & 0.053 & 0.600 & 0.000 & 0.450 & 5.803 & 1.7329 & -75.74 & 35 \\
\hline & & & & & & & & \\
\hline Additional Indirect values & & & & & & & & \\
\hline 1-Pentanol & 0.219 & 0.42 & 0.37 & 0.48 & 3.106 & 0.8718 & -47.67 & 40 \\
\hline Aniline & 0.955 & 0.96 & 0.26 & 0.41 & 3.934 & 0.8162 & -60.64 & 40 \\
\hline 4-Methylphenol & 0.82 & 0.87 & 0.57 & 0.31 & 4.312 & 0.9160 & -60.64 & 40 \\
\hline
\end{tabular}


TABLE 2. Values of the gas to 1,2-dichloroethane solvation enthalpy, $\Delta \mathrm{H}_{\text {Solv,DCE}}$, in

$\mathrm{kJ} / \mathrm{mole}$ at $298 \mathrm{~K}$ for 88 solutes, together with the solute descriptors

\begin{tabular}{|c|c|c|c|c|c|c|c|c|}
\hline Solute & E & s & A & B & L & V & Exp Value & Ref \\
\hline Pentane & 0.000 & 0.000 & 0.000 & 0.000 & 2.162 & 0.8131 & -18.87 & 42 \\
\hline Hexane & 0.000 & 0.000 & 0.000 & 0.000 & 2.668 & 0.9540 & -22.80 & 42 \\
\hline Heptane & 0.000 & 0.000 & 0.000 & 0.000 & 3.173 & 1.0949 & -26.57 & 42 \\
\hline Octane & 0.000 & 0.000 & 0.000 & 0.000 & 3.677 & 1.2358 & -30.25 & 42 \\
\hline Nonane & 0.000 & 0.000 & 0.000 & 0.000 & 4.182 & 1.3767 & -34.52 & 42 \\
\hline Decane & 0.000 & 0.000 & 0.000 & 0.000 & 4.686 & 1.5176 & -38.53 & 42 \\
\hline Undecane & 0.000 & 0.000 & 0.000 & 0.000 & 5.191 & 1.6585 & -45.70 & 48 \\
\hline Dodecane & 0.000 & 0.000 & 0.000 & 0.000 & 5.696 & 1.7994 & -46.02 & 42 \\
\hline Tridecane & 0.000 & 0.000 & 0.000 & 0.000 & 6.200 & 1.9402 & -54.15 & 49 \\
\hline Tetradecane & 0.000 & 0.000 & 0.000 & 0.000 & 6.705 & 2.0810 & -57.35 & 59 \\
\hline Pentadecane & 0.000 & 0.000 & 0.000 & 0.000 & 7.209 & 2.2220 & -61.54 & 50 \\
\hline Hexadecane & 0.000 & 0.000 & 0.000 & 0.000 & 7.714 & 2.3630 & -61.55 & 42 \\
\hline Heptadecane & 0.000 & 0.000 & 0.000 & 0.000 & 8.218 & 2.5040 & -71.71 & 51 \\
\hline 3-Ethylpentane & 0.000 & 0.000 & 0.000 & 0.000 & 3.091 & 0.9540 & -27.00 & 45 \\
\hline 2,2,4-Trimethylpentane & 0.000 & 0.000 & 0.000 & 0.000 & 3.106 & 1.2358 & -27.13 & 7 \\
\hline 2,2,4,4-Tetramethylpentane & 0.000 & 0.000 & 0.000 & 0.000 & 3.512 & 1.3767 & -28.70 & 45 \\
\hline Cyclohexane & 0.305 & 0.100 & 0.000 & 0.000 & 2.964 & 0.8454 & -25.60 & 45 \\
\hline Acetone & 0.179 & 0.700 & 0.040 & 0.490 & 1.696 & 0.5470 & -32.89 & 43 \\
\hline 2-Butanone & 0.166 & 0.700 & 0.000 & 0.510 & 2.287 & 0.6879 & -36.36 & 43 \\
\hline 2-Hexanone & 0.136 & 0.680 & 0.000 & 0.510 & 3.286 & 0.9697 & -46.00 & 45 \\
\hline 2-Heptanone & 0.123 & 0.680 & 0.000 & 0.510 & 3.760 & 1.1106 & -47.49 & 43 \\
\hline 4-Heptanone & 0.110 & 0.660 & 0.000 & 0.510 & 3.705 & 1.1106 & -45.98 & 43 \\
\hline 2-Nonanone & 0.119 & 0.680 & 0.000 & 0.510 & 4.735 & 1.3924 & -55.10 & 43 \\
\hline 5-Nonanone & 0.103 & 0.660 & 0.000 & 0.510 & 4.698 & 1.3924 & -53.14 & 43 \\
\hline 2,2,4,4-Tetramethyl-3-pentanone & 0.099 & 0.560 & 0.000 & 0.520 & 4.370 & 1.3924 & -44.30 & 43 \\
\hline Cyclohexanone & 0.403 & 0.860 & 0.000 & 0.560 & 3.792 & 0.8610 & -47.15 & 43 \\
\hline Methanol & 0.278 & 0.440 & 0.430 & 0.470 & 0.970 & 0.3082 & -23.83 & 52 \\
\hline Ethanol & 0.246 & 0.420 & 0.370 & 0.480 & 1.485 & 0.4491 & -26.85 & 52 \\
\hline 1-Propanol & 0.236 & 0.420 & 0.370 & 0.480 & 2.031 & 0.5900 & -29.75 & 52 \\
\hline 1-Butanol & 0.224 & 0.420 & 0.370 & 0.480 & 2.601 & 0.7309 & -35.74 & 52 \\
\hline 1-Octanol & 0.199 & 0.420 & 0.370 & 0.480 & 4.619 & 1.2950 & -52.13 & 46 \\
\hline Diethyl ether & 0.041 & 0.250 & 0.000 & 0.450 & 2.015 & 0.7309 & -27.10 & 45 \\
\hline Dibutyl ether & 0.000 & 0.250 & 0.000 & 0.450 & 3.924 & 1.2945 & -40.08 & 46 \\
\hline Butyl methyl Ether & 0.045 & 0.250 & 0.000 & 0.440 & 2.658 & 0.8718 & -31.50 & 45 \\
\hline Methyl tert-butyl ether & 0.024 & 0.210 & 0.000 & 0.590 & 2.380 & 0.8718 & -30.80 & 45 \\
\hline Methyl heptyl ether & 0.048 & 0.250 & 0.000 & 0.450 & 4.088 & 1.2945 & -43.60 & 46 \\
\hline Tetrahydrofuran & 0.289 & 0.520 & 0.000 & 0.480 & 2.636 & 0.6223 & -33.90 & 45 \\
\hline 1,4-Dioxane & 0.329 & 0.750 & 0.000 & 0.640 & 2.892 & 0.6810 & -39.30 & 45 \\
\hline 15-Crown-5 & 0.410 & 1.200 & 0.000 & 1.750 & 6.779 & 1.7025 & -90.57 & 53 \\
\hline 1-Fluorooctane & -0.020 & 0.350 & 0.000 & 0.100 & 3.850 & 1.2538 & -44.69 & 46 \\
\hline
\end{tabular}




\begin{tabular}{|c|c|c|c|c|c|c|c|c|}
\hline 1-Chlorooctane & 0.191 & 0.400 & 0.000 & 0.090 & 4.708 & 1.3580 & -48.07 & 46 \\
\hline Naphthalene & 1.340 & 0.920 & 0.000 & 0.200 & 5.161 & 1.0854 & -54.79 & 60 \\
\hline Methyl formate & 0.192 & 0.680 & 0.000 & 0.380 & 1.285 & 0.4648 & -28.22 & 54 \\
\hline Methyl acetate & 0.142 & 0.640 & 0.000 & 0.450 & 1.911 & 0.6057 & -33.38 & 44 \\
\hline Ethyl acetate & 0.106 & 0.620 & 0.000 & 0.450 & 2.314 & 0.7466 & -36.00 & 45 \\
\hline Propyl acetate & 0.092 & 0.600 & 0.000 & 0.450 & 2.819 & 0.8875 & -39.79 & 44 \\
\hline Butyl acetate & 0.071 & 0.600 & 0.000 & 0.450 & 3.353 & 1.0284 & -44.53 & 44 \\
\hline Pentyl acetate & 0.067 & 0.600 & 0.000 & 0.450 & 3.844 & 1.1693 & -47.30 & 44 \\
\hline Methyl propanoate & 0.128 & 0.600 & 0.000 & 0.450 & 2.431 & 0.7466 & -36.75 & 54 \\
\hline Ethyl propanoate & 0.087 & 0.580 & 0.000 & 0.450 & 2.807 & 0.8875 & -37.94 & 44 \\
\hline Methyl butanoate & 0.106 & 0.600 & 0.000 & 0.450 & 2.893 & 0.8875 & -40.29 & 54 \\
\hline Ethyl butanoate & 0.068 & 0.580 & 0.000 & 0.450 & 3.271 & 1.0284 & -41.86 & 44 \\
\hline Methyl pentanoate & 0.108 & 0.600 & 0.000 & 0.450 & 3.392 & 1.0284 & -43.97 & 54 \\
\hline Ethyl pentanoate & 0.049 & 0.580 & 0.000 & 0.450 & 3.769 & 1.1693 & -47.81 & 47 \\
\hline Ethyl hexanoate & 0.043 & 0.580 & 0.000 & 0.450 & 4.251 & 1.3102 & -50.46 & 44 \\
\hline Butyl formate & 0.121 & 0.630 & 0.000 & 0.380 & 2.958 & 0.8875 & -41.21 & 55 \\
\hline Acetonitrile & 0.237 & 0.900 & 0.070 & 0.320 & 1.739 & 0.4042 & -33.10 & 45 \\
\hline Triethylamine & 0.101 & 0.150 & 0.000 & 0.790 & 3.040 & 1.0538 & -33.20 & 45 \\
\hline \begin{tabular}{|l|} 
Benzene \\
\end{tabular} & 0.610 & 0.520 & 0.000 & 0.140 & 2.786 & 0.7176 & -33.50 & 45 \\
\hline Fluorobenzene & 0.477 & 0.570 & 0.000 & 0.100 & 2.788 & 0.7341 & -34.70 & 45 \\
\hline Chlorobenzene & 0.718 & 0.650 & 0.000 & 0.070 & 3.657 & 0.8388 & -38.90 & 45 \\
\hline Bromobenzene & 0.882 & 0.730 & 0.000 & 0.090 & 4.041 & 0.8914 & -42.70 & 45 \\
\hline lodobenzene & 1.188 & 0.820 & 0.000 & 0.120 & 4.502 & 0.9746 & -47.70 & 45 \\
\hline 1,2-Dichlorobenzene & 0.872 & 0.780 & 0.000 & 0.040 & 4.518 & 0.9612 & -46.00 & 45 \\
\hline 1,4-Dichlorobenzene & 0.825 & 0.750 & 0.000 & 0.020 & 4.435 & 0.9612 & -45.20 & 45 \\
\hline Biphenyl & 1.360 & 0.990 & 0.000 & 0.260 & 6.014 & 1.3240 & -64.00 & 45 \\
\hline Anthracene & 2.290 & 1.340 & 0.000 & 0.280 & 7.568 & 1.4540 & -76.60 & 45 \\
\hline Toluene & 0.601 & 0.520 & 0.000 & 0.140 & 3.325 & 0.8573 & -37.70 & 45 \\
\hline Mesitylene & 0.649 & 0.520 & 0.000 & 0.190 & 4.344 & 1.1391 & -45.20 & 45 \\
\hline Pyridine & 0.631 & 0.840 & 0.000 & 0.520 & 3.022 & 0.6753 & -40.60 & 45 \\
\hline Nitrobenzene & 0.871 & 1.110 & 0.000 & 0.280 & 4.557 & 0.8906 & -54.80 & 45 \\
\hline Anisole & 0.710 & 0.750 & 0.000 & 0.290 & 3.890 & 0.9160 & -46.90 & 45 \\
\hline Acetophenone & 0.818 & 1.010 & 0.000 & 0.480 & 4.501 & 1.0140 & -56.50 & 45 \\
\hline 4-Methoxyphenol & 0.900 & 1.170 & 0.570 & 0.480 & 4.773 & 0.9747 & -68.60 & 65 \\
\hline 1,2-Dichloroethane & 0.416 & 0.640 & 0.100 & 0.110 & 2.573 & 0.6352 & -35.10 & 66 \\
\hline Diethyl carbonate & 0.060 & 0.580 & 0.000 & 0.530 & 3.412 & 0.9462 & -45.02 & 56 \\
\hline Carbon tetrachloride & 0.458 & 0.380 & 0.000 & 0.000 & 2.823 & 0.7391 & -31.87 & 58 \\
\hline Sulfur dioxide & 0.370 & 0.660 & 0.280 & 0.100 & 0.778 & 0.3465 & -23.01 & 61 \\
\hline Dimethyl carbonate & 0.142 & 0.540 & 0.000 & 0.570 & 2.328 & 0.6644 & -38.14 & 57 \\
\hline 1-Chloronaphthalene & 1.417 & 1.000 & 0.000 & 0.140 & 5.856 & 1.2078 & -62.25 & 56 \\
\hline Nitromethane & 0.313 & 0.950 & 0.060 & 0.310 & 1.892 & 0.4237 & -34.84 & 39 \\
\hline Nitroethane & 0.270 & 0.950 & 0.020 & 0.330 & 2.414 & 0.5646 & -38.15 & 39 \\
\hline Propionitrile & 0.162 & 0.900 & 0.020 & 0.360 & 2.082 & 0.5451 & -35.03 & 39 \\
\hline
\end{tabular}




\begin{tabular}{|l|l|l|l|l|l|l|l|l|}
\hline 1 -Chlorobutane & 0.210 & 0.400 & 0.000 & 0.100 & 2.722 & 0.7946 & -31.95 & 62 \\
\hline $1,1,1-$ Trichloroethane & 0.369 & 0.410 & 0.000 & 0.090 & 2.733 & 0.7576 & -31.28 & 63 \\
\hline trans 1,2-Dichloroethene & 0.425 & 0.410 & 0.090 & 0.050 & 2.278 & 0.5922 & -28.91 & 64 \\
\hline $1,1,2,2-$ Tetrachloroethane & 0.595 & 0.760 & 0.160 & 0.120 & 3.803 & 0.8800 & -47.03 & 64 \\
\hline Benzaldehyde & 0.820 & 1.000 & 0.000 & 0.390 & 4.008 & 0.8730 & -50.60 & 45 \\
\hline
\end{tabular}




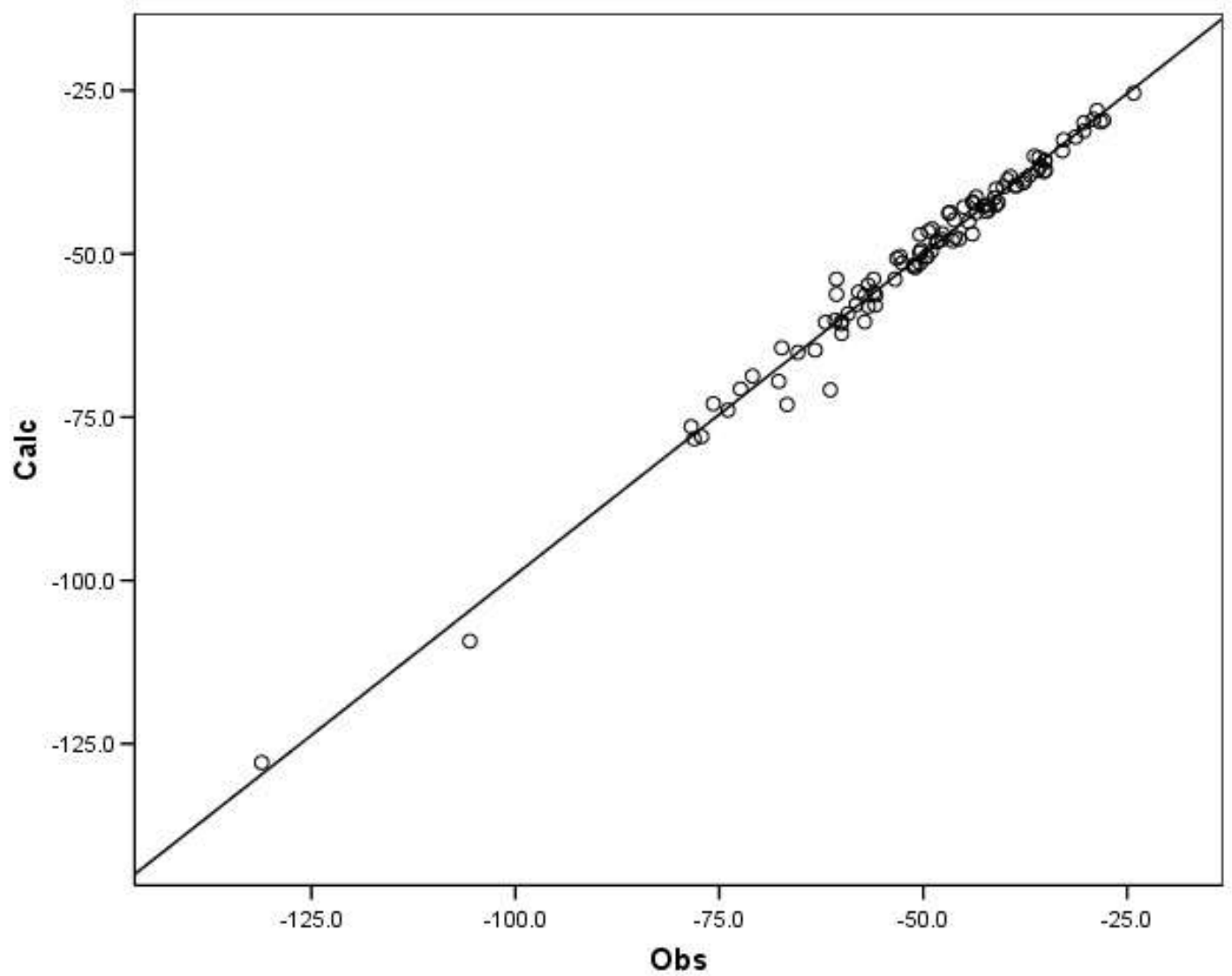

Figure 1. A plot of the calculated values of $\Delta \mathrm{H}_{\text {Solv,CFM }}$ on eqn (11) against the observed values. 


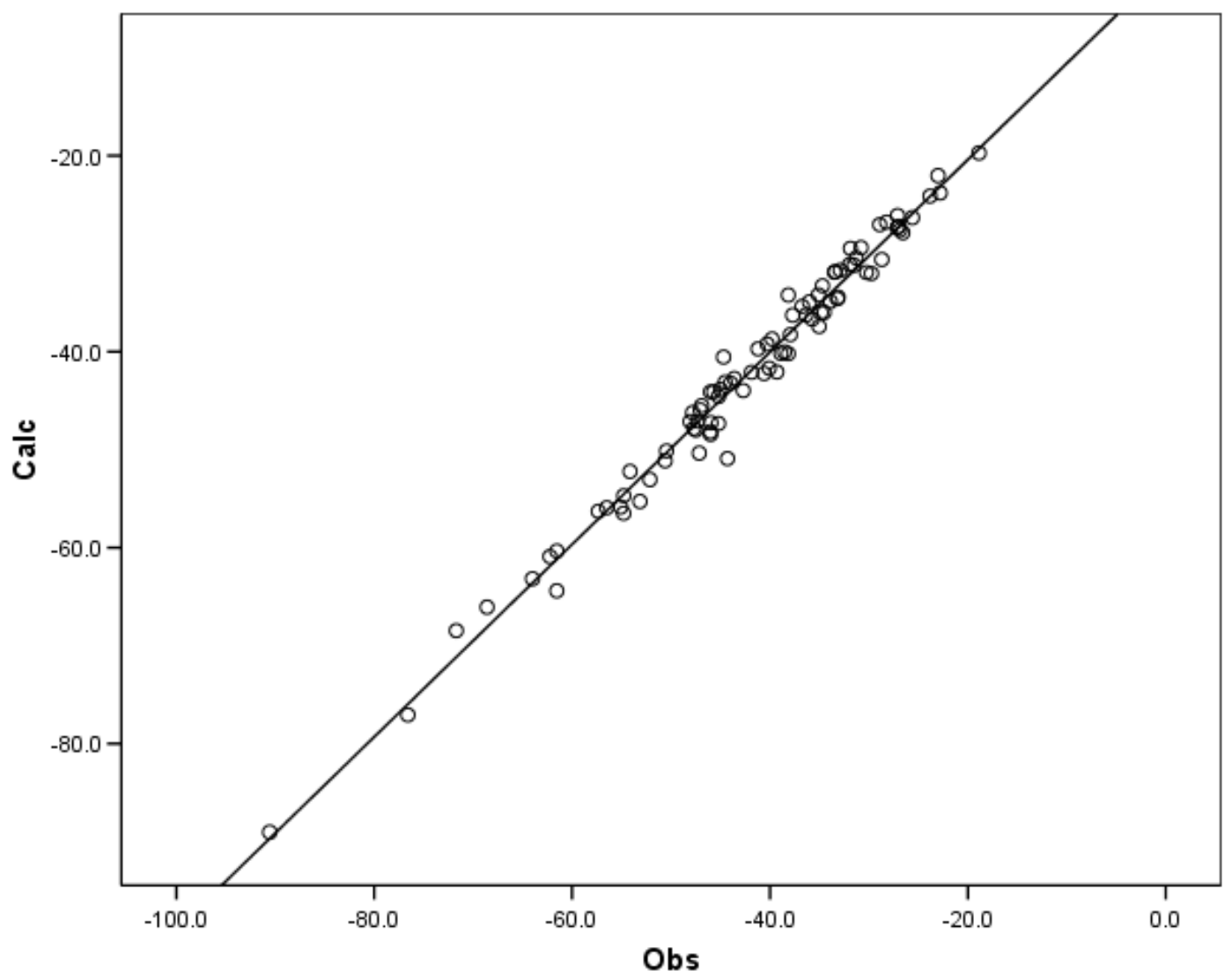

Figure 2. A plot of the calculated values of $\Delta \mathrm{H}_{\text {Solv,DCE }}$ on eqn (14) against the observed values 